\title{
Obituaries
}

Obituaries should be submitted by email to Jadene Doak at jadene.doak@springernature.com

All submitted obituaries should be 400 words maximum in length (apart from obituaries for past presidents of the BDA where the length should be 800 words).

Content of the obituary is down to the individual author, and the approval of the family should be given for the obituary prior to submission to the BDJ.

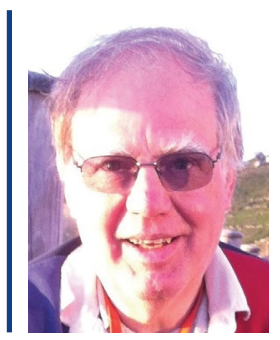

John Potts

1947-2021

Dr John Potts was born in Lier, Belgium. He qualified BDS from Manchester Dental School in 1972, completing an intercalated $\mathrm{BSc}$, gaining a double first and winning the Charles Henry Preston Prize, awarded to the top dental student. Trained in pathology and gaining his FRCPath, he worked in Birmingham Dental Hospital and School of Dentistry until moving to Cardiff in 1992 as a senior lecturer/consultant in oral pathology. For many years, he worked in pathology, as well as contributing to oral medicine clinics.

Dr Potts supported clinical services, playing a crucial role in the care of many thousands of patients, his diagnoses being crucial to the management of those with the most serious orofacial diseases.

An enthusiastic teacher, John played a key role in providing clinical and technical input to the digitisation of services in the Dental Hospital and School, overseeing the introduction of computers to all clinical areas. He was instrumental in introducing the SALUD and LIFT-UP systems in the clinics.

For many years, John chaired the library committee and played a crucial role in ensuring that library and study facilities in Cardiff Dental Hospital and School were amongst the most comprehensive in the UK.

John was one of six founder members of the British Society for Oral Medicine. The society recognised John's contributions to oral medicine and the society, awarding him Honorary Fellowship in 2016.

He was an external examiner for other dental schools, and for a period of time covered oral pathology for another dental hospital in addition to his role in Cardiff.

A lifelong Manchester United supporter, he got to see them one final time in early 2020. In his youth, he played hockey for his school and university, and played in staff/ student games at Birmingham University. He also enjoyed squash, mountain climbing, and was part of Kendal Mountain Search \& Rescue Team. A keen walker, he remained a member of a local walking group with Angus his dog until the first lockdown.

He mentored several people, from students to consultants, who have commented on how kind and supportive he was towards them.

Dr Potts continued working for Cardiff University Dental Hospital and School after the onset of serious illness, which he fought valiantly and with spirit, joining online meetings until recent weeks.

He is survived by his wife Kay, children Lindsay \& Christopher (Alison died in 2014). Kay Potts and Lindsay Roberts

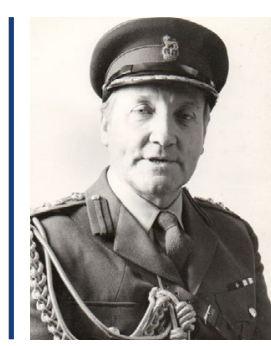

\section{Colonel Richard (Dick) Docherty}

1927-2021

Dick Docherty died on 29 June 2021, back in his beloved Scotland where he had spent the last years of a long, happy and successful life among his family and friends. He was born in 1927 and qualified at Glasgow Dental School in 1951 . He was immediately conscripted for National Service, commissioned into the Royal Army Dental Corps (RADC) and posted to The Station Hospital, Khartoum, where he met Anne, a theatre sister, whom he courted relentlessly for the next three years. He was demobilised from there two years later and returned to Scotland, marrying
Anne in 1955 and spending eight years in general practice, during which time his sons Christopher and Richard were born.

But in 1962, Dick applied to rejoin the RADC. Although he was above the age limit, his old Khartoum boss, now a General, had 'happy memories of the excellent work put in at Khartoum' and saw 'no difficulty in his age being treated with considerable latitude.' Unsurprisingly, he was re-admitted, commissioned as Major, posted directly to Tripoli and thence to Benghazi in 1966. The following year, now a Lieutenant Colonel, he left for the BAOR Corps Dental Laboratory in Düsseldorf, where began his interest in dental prosthetics. Thus, in 1971, he was selected to study this speciality at the Eastman Dental Hospital, leaving with an MSc a year later to take command of the Corps UK Dental Laboratory in Aldershot. He returned to Düsseldorf in 1976 and was promoted to Colonel the following year, moving to the MOD as the Assistant Director, Army Dental Services. Whilst there, he was awarded a Fellowship of the Chartered Management Institute.

In 1980, he returned to Corps Headquarters as Commandant, being admitted into the Order of St John later that year and appointed the Queen's Honorary Dental Surgeon in 1982. Then, it was Germany again in 1984, until retirement in 1986. He then worked as a Civilian Dental Practitioner at Winchester, serving as Colonel Commandant from 1988 until his final retirement in 1993.

Dick had his life completely changed by National Service, discovering a lifestyle into which he fitted perfectly, as shown by his subsequent success therein and the very many friends he made en route. He will be greatly missed by these and even more so by Christopher and Richard, and his grandchildren, Alex, Daniel and Hannah.

Philip Horobin 